\title{
COMPETIVENESS OF THE HUNGARIAN PIG SECTOR
}

\author{
Andrea Bartha PhD student
}

\section{University of Debrecen, Faculty of Applied Economics and Rural Development barthaa@agr.unideb.hu}

\begin{abstract}
The number of Hungarian pig population was 3.2 million in February 2010, 150 thousand less than in the previous year. This included 226 thousand brood sows, 54 thousand less than in the previous year, and this number is expected to fall further next year. In the past two years the number of brood sows decreased to a larger extent in economic organizations than in private farms (KSH, 2010). Despite the rising costs of feedingstuffs, producer prices for slaughter pigs have decreased, therefore private farms with small herds of brood sows have sold their breeding animals for slaughterhouses. However, economic organizations mostly tried to restructure their production and place emphasis on plant production, thus improving their situation.

These market changes indicate that the sector continues to scale down, production shrinks, market losses are continuous within the sector and vulnerability threaten the players of the product cycle increasingly.
\end{abstract}

Key words: Pig production, Consumption, Competitiveness, Sector analysis

\section{Introduction}

Developing Hungarian pig production has ceased to exist for a long time; in addition, the most crucial problem is posed by the deterioration of its international competitiveness. However, it is to be highlighted that these competitive disadvantages are not merely due to national insufficiencies. The effects of international markets on demand - supply also play a significant role, both in terms of product quality and price (AKI, 2009).

The above mentioned facts lead to conclude that the analysis of the sector on the level of product cycle is justified in order to highlight the reasons of its decline. From producers to trade each and every economic player needs to analyze their competitiveness, efficiency and income and then identify the key problems. To maintain the sector ready for appropriate operation all the players need to produce competitively, as no competitive processing industry exists without the production of quality source material; similarly, no easy-to-sell products exist without a meat sector which functions appropriately; these statements are valid backwards as well (Udovecz, 2008).

\section{Methods}

To unveil the conditions - objective and subjective competitive disadvantages that hinder development - and gain a lifelike analysis, mostly prominent national and international agricultural, food-industrial and trade enterprises, organizations were visited. Sincere discussions took place with several lead experts. "Representativity" was not a conscious objective, as competitive options can be evaluated realistically from the viewpoint of significant economic players. The opinions given by the addressed practical experts were collected and a comprehensive table was prepared which includes all the problems on product cycle level to determine the results and also to cease the reason of the problem. Examination was carried out to find out what measures for the improvement or the removal of the problem had been carried out so far. Finally, in certain cases, recommendations were made for the explored problems.

From the very outset, our research was characterized by the unity of theory and practice (usefulness), the merge of international and national viewpoints and ideas related to product cycles. There is no competitive agriculture without competitive processing and trade; there is no practiceoriented education without research! Naturally, realistic guidelines are also vital! (AKI, 2009).

I take the view that information on the improvement potentials of competitive options, correlations and expert opinions provide a sound proof for the identification of state tasks, and also for agro-economic players to assess their own strengths and to develop their long-term business policies. Hopefully, the present study will serve as a key pillar for the establishment of a realistic and modern agricultural strategy. The present research seeks to map out the SWOT analysis of the sector on the grounds of this table, followed by the creation of a problem-tree and a target-tree to provide solutions how to improve areas suffering from competitive disadvantages.

\section{Results}

Hungary has particularly blatant problems of competitiveness in several areas. Above all, the judgement of our taxation system is dramatically poor. Not only tax rates, but the effects of taxes and supports in the distortion of 
Table 1: Competitive disadvantages on macro-economic level

\begin{tabular}{|c|c|c|c|c|}
\hline $\begin{array}{l}\text { Competitive } \\
\text { disadvantages on macro- } \\
\text { economic level }\end{array}$ & REASON & RESULT & Measures taken so far & $\begin{array}{l}\text { Suggestions for the } \\
\text { solution }\end{array}$ \\
\hline $\begin{array}{l}\text { Tax, contribution and } \\
\text { administrative burdens }\end{array}$ & $\begin{array}{l}\text { Personal Income tax, VAT, social } \\
\text { security contributions, employers' } \\
\text { contribution, employees' } \\
\text { contributions, costs of business } \\
\text { start-ups }\end{array}$ & $\begin{array}{l}\text { Black economy } 30 \% \\
\text { (trade, employment) }\end{array}$ & $\begin{array}{l}\text { Standard tax system, } \\
\text { tax law??? }\end{array}$ & $\begin{array}{l}\text { Reduction, rationalization } \\
\text { of VAT and administrative } \\
\text { burdens, elimination } \\
\text { of bureaucracy }\end{array}$ \\
\hline Support policy & $\begin{array}{l}\text { Haphazard, occasional and } \\
\text { not renewing }\end{array}$ & $\begin{array}{l}\text { Pig keeping is not supported, } \\
\text { so farmers are "helped" in } \\
\text { several ways }\end{array}$ & $\begin{array}{l}\text { EU regulation, no free } \\
\text { activities, frittered support } \\
\text { AGENDA } 2000\end{array}$ & $\begin{array}{l}\text { Standard, clear support } \\
\text { policy on national level }\end{array}$ \\
\hline Land policy & Separated property & $\begin{array}{l}\text { No feedingstuff for individual } \\
\text { owners, guarantee for loan } \\
\text { requests; difficulties of land } \\
\text { rent and costs increase }\end{array}$ & $\begin{array}{l}\text { Support for access to land, } \\
\text { diversification, merging } \\
\text { farms, Act on Arable Land }\end{array}$ & Integration \\
\hline Logistics & $\begin{array}{l}\text { Geographical disadvantage } \\
\text { Disorganized transport } \\
\text { Irrational system of supply }\end{array}$ & $\begin{array}{l}\text { Lack of seaports } \\
\text { Railway transportation is } \\
\text { slow and obsolete } \\
\text { Quality of road network is } \\
\text { questionable } \\
\text { Slaughter -processing } \\
\text { are separated }\end{array}$ & $\begin{array}{l}\text { Motorway construction } \\
\text { Concentration in certain } \\
\text { premises on larger farms } \\
\text { Pick Zrt. }\end{array}$ & \\
\hline Commercial chains & Standards, compliance, ethics & $\begin{array}{l}\text { Domestic products can } \\
\text { hardly compete with } \\
\text { depressed prices, old } \\
\text { suppliers are privileged }\end{array}$ & $\begin{array}{l}80-20 \% \\
\text { Ethical code? }\end{array}$ & $\begin{array}{l}\text { Integration } \\
\text { Bargaining position } \\
\text { Homogenous, large quantity } \\
\text { and good quality of goods } \\
\text { ensured in the long run }\end{array}$ \\
\hline $\begin{array}{l}\text { Social problems confidence } \\
\text { and morals }\end{array}$ & $\begin{array}{l}\text { Inheritance of the past, morals, } \\
\text { safety of property corruption }\end{array}$ & $\begin{array}{l}\text { Joining forces, joint property } \\
\text { are out of the question }\end{array}$ & $\begin{array}{l}\text { Network of consultancy, } \\
\text { TCS (Producer Groups) - } \\
\text { BÉSZs (Cooperatives for } \\
\text { Purchase and Sales) }\end{array}$ & $\begin{array}{l}\text { Initiatives carried out in } \\
\text { favour of integration }\end{array}$ \\
\hline Commitment & Lack of management, cooperation & Owners' interests are different & & \\
\hline
\end{tabular}

Source: author' own collection

competition are heavily criticized. On the other hand, high taxes are coupled with the poor quality of public services: general opinion about law enforcement, health care but primarily about welfare policies for the reduction of unequal opportunities is especially negative. Moreover, Hungarian competitiveness is in a disadvantageous position regarding the investigated indicators of both education and training (Bartha, 2008).

This brings us to the next issue, the introduction of competitive disadvantages investigated on macro-economic level in terms of agricultural production. In addition, besides extremely high, obscure and chaotic taxes which impede efficient production, contributions and administrative costs are also considerable high, thereby further exacerbating the situation. Our support policy has been realized without thorough consideration on various levels and the pig sector was primarily hit by this period. The insufficiency of external resources and deductions is only one item on the list of factors which inflicted the players of Hungarian pig sector.

The formation of the Hungarian holding system is to be mentioned: it clearly hinders economical production as the majority of pig farmers do not possess private lands which would serve as a basis for feedingstuff production and potential capital acquisition. Besides all these hardships, Hungary also has to cope with its disadvantageous geographical location: there is no seaport, shipping on the Danube is restricted, the railway network is slow and has also become obsolete; therefore our export opportunities are limited into third countries. In the past couple of years motorway construction improved the potentials of inland transportation but it has opened the windows of export opportunities only into nearby countries.

In contrast with such kind of infrastructure development the retail traders who set up businesses in Hungary prefer rather their own suppliers at the expense of Hungarian producers and products. They stipulate high requirements and costly standards rendering it impossible for Hungarian products to be available in hyper-and supermarkets. The only solution might be joint action, cooperation and support, which could improve our bargaining positions, uphold and promote the Hungarian will. To achieve this, Hungarian mentality has to go through considerable changes.

With a paradigm-shift, let us start the further investigation of competitive disadvantages on product cycle 
Table 2: Competitive disadvantages on consumption level

\begin{tabular}{|c|c|c|c|c|}
\hline $\begin{array}{l}\text { Competitive } \\
\text { disadvantages on } \\
\text { consumption level }\end{array}$ & REASON & RESULT & Measures taken so far & $\begin{array}{l}\text { Suggestions for the } \\
\text { solution }\end{array}$ \\
\hline Growing consumption & Lack of technological background & Demand is not met & & $\begin{array}{l}\text { Capital into the sector, } \\
\text { takeover of technology } \\
\text { and genetics }\end{array}$ \\
\hline $\begin{array}{l}\text { Healthy diet has gained } \\
\text { ground }\end{array}$ & Impact of media & $\begin{array}{l}\text { The ratio of poultry meat and } \\
\text { pork is instable }\end{array}$ & Trademarks & $\begin{array}{l}\text { Community communication } \\
\text { to clarify misbelief }\end{array}$ \\
\hline $\begin{array}{l}\text { Growing demand for } \\
\text { premium products }\end{array}$ & $\begin{array}{l}\text { Accelerated life, conscious } \\
\text { food intake }\end{array}$ & Processed products & & $\begin{array}{l}\text { Keeping abreast of the } \\
\text { market, fast reactions }\end{array}$ \\
\hline Diverse consumer attitudes & $\begin{array}{l}\text { Different animal body regions are } \\
\text { preferred in different regions }\end{array}$ & $\begin{array}{l}\text { Not every product is } \\
\text { quick-selling on markets }\end{array}$ & & $\begin{array}{l}\text { A good system of distribution } \\
\text { is needed by eliminating } \\
\text { inequalities in processing }\end{array}$ \\
\hline $\begin{array}{l}\text { Consumers depend on } \\
\text { sales and prices }\end{array}$ & Price sensitivity & $\begin{array}{l}\text { Customers always look for } \\
\text { products on sale, by adjusting } \\
\text { their eating habits; } \\
\text { permanently low meat prices }\end{array}$ & & \\
\hline Seasonal impact & $\begin{array}{l}\text { Demand for meat and meat } \\
\text { products changes }\end{array}$ & $\begin{array}{l}\text { Concentration, storing, } \\
\text { warehousing are difficult, } \\
\text { deep-frozen pork is not } \\
\text { marketable }\end{array}$ & & $\begin{array}{l}\text { Diversification in several } \\
\text { regions, exploitation on } \\
\text { demand-dependent markets }\end{array}$ \\
\hline Lack of loyalty & $\begin{array}{l}\text { Hungarian products are not } \\
\text { "strong" trademarks }\end{array}$ & Import intake & & $\begin{array}{l}\text { Restoration of the fame of } \\
\text { Hungarian products }\end{array}$ \\
\hline
\end{tabular}

Source: author' own collection

level with production. The whole analysis is based on changing this approach. I have come to the realization that consumers and consumption are the drivers everywhere. In the present market-economy only those can survive who can react as fast as possible to changes in consumer attitudes and markets. Hungarian pork consumption is basically determined by its price. Domestic consumers are rather price-sensitive and dependent on sales; therefore they are not loyal to Hungarian products. Therefore, cheap import meat and meat products could become ready-selling on Hungarian markets (Szakály, et al., 2008).

Mention must be made on seasonality and diverse regional consumer attitudes on regional level. This can only be eliminated by diversification. None of the processing

Table 3: Competitive disadvantages on commercial level

\begin{tabular}{|c|c|c|c|c|}
\hline $\begin{array}{l}\text { Competitive } \\
\text { disadvantages on } \\
\text { commercial level }\end{array}$ & REASON & RESULT & Measures taken so far & $\begin{array}{l}\text { Suggestions for the } \\
\text { solution }\end{array}$ \\
\hline $\begin{array}{l}\text { Counter for fresh carcass } \\
\text { meat ceases }\end{array}$ & Consumer attitudes change & $\begin{array}{l}\text { Prepared, packaged meat } \\
\text { products are ready selling }\end{array}$ & & \\
\hline $\begin{array}{l}\text { Prepared products are } \\
\text { marketed at higher prices }\end{array}$ & Higher added value & $\begin{array}{l}\text { Price rise is not accepted by } \\
\text { retailers }\end{array}$ & & $\begin{array}{l}\text { Joining of forces, } \\
\text { improvement of bargaining } \\
\text { positions }\end{array}$ \\
\hline $\begin{array}{l}\text { Excess supply for meat } \\
\text { preparations }\end{array}$ & $\begin{array}{l}\text { Processors cannot promote } \\
\text { their products }\end{array}$ & $\begin{array}{l}\text { Retailers choose what is } \\
\text { cheaper }\end{array}$ & & \\
\hline $\begin{array}{l}\text { Excess number of stores } \\
\text { in one place }\end{array}$ & Undercut effect & $\begin{array}{l}\text { Prices are even more difficult } \\
\text { to realize prices }\end{array}$ & & $\begin{array}{l}\text { Maximization of retail shops } \\
\text { for the population or for a } \\
\text { given area }\end{array}$ \\
\hline $\begin{array}{l}\text { Branded products gain } \\
\text { ground in trade }\end{array}$ & $\begin{array}{l}\text { Lower prices, higher price } \\
\text { competition }\end{array}$ & Lower quality & & $\begin{array}{l}\text { No competitiveness on the } \\
\text { mass-product market, unique } \\
\text { domestic products }\end{array}$ \\
\hline $\begin{array}{l}\text { Difficulties of contracts } \\
\text { between retailers and } \\
\text { Hungarian suppliers }\end{array}$ & $\begin{array}{l}\text { Long-term contractual relations } \\
\text { with "foreign" partners }\end{array}$ & $\begin{array}{l}\text { The distribution of Hungarian } \\
\text { products is limited }\end{array}$ & Ethical code & $\begin{array}{l}\text { Favourable bargaining } \\
\text { position can be gained by } \\
\text { standard, good quality goods } \\
\text { in the required quantity }\end{array}$ \\
\hline Date of payment & $\begin{array}{l}\text { Production difficulty in both } \\
\text { directions of the product cycle }\end{array}$ & $\begin{array}{l}\text { Liquidity is difficult to } \\
\text { maintain, go-round debts }\end{array}$ & $\begin{array}{l}\text { Regulation on payment dates, } \\
\text { Law of XVI. } 2003 \text { on the } \\
\text { Organization of an } \\
\text { Agricultural Market }\end{array}$ & $\begin{array}{l}\text { Long term contracts, } \\
\text { fixed payment dates }\end{array}$ \\
\hline
\end{tabular}


Table 4: Competitive disadvantages on the level of processing

\begin{tabular}{|c|c|c|c|c|}
\hline $\begin{array}{l}\text { Competitive } \\
\text { disadvantages on the level } \\
\text { of processing }\end{array}$ & REASON & RESULT & Measures taken so far & $\begin{array}{l}\text { Suggestions for the } \\
\text { solution }\end{array}$ \\
\hline Concentration & $\begin{array}{l}\text { Lack of capital, specialization } \\
\text { is not solved }\end{array}$ & $\begin{array}{l}\text { Slaughter-cutting-product } \\
\text { manufacturing are merged }\end{array}$ & & $\begin{array}{l}\text { Separation on the level of } \\
\text { farms }\end{array}$ \\
\hline Lack of contractual relations & $\begin{array}{l}\text { No long-term agreements, rather } \\
\text { oral deals are typical }\end{array}$ & $\begin{array}{l}\text { Standard source material } \\
\text { (quality, quantity) is not } \\
\text { provided }\end{array}$ & & Contract \\
\hline $\begin{array}{l}\text { BÉSZs (Cooperatives for } \\
\text { Purchase and Sales) }\end{array}$ & $\begin{array}{l}\text { Unity of action, but individual } \\
\text { sales are also maintained }\end{array}$ & $\begin{array}{l}\text { Standard products are difficult } \\
\text { to be provided for processors, } \\
\text { source material supply is } \\
\text { unpredictable }\end{array}$ & & $\begin{array}{l}\text { Sales through BÉSZs only } \\
\text { under strict regulation }\end{array}$ \\
\hline Bargaining position & Pressure by commercial chains & $\begin{array}{l}\text { Looking for cheap base } \\
\text { material resources, mainly } \\
\text { from import }\end{array}$ & & $\begin{array}{l}\text { Two-way long-term } \\
\text { contractual relation }\end{array}$ \\
\hline Payment morals & $\begin{array}{l}\text { Production difficulties in both } \\
\text { directions of the product cycle }\end{array}$ & $\begin{array}{l}\text { Liquidity is difficult to } \\
\text { maintain, go-round debt }\end{array}$ & $\begin{array}{l}\text { Regulations on payment } \\
\text { deadlines, Law of XVI. } 2003 \\
\text { on the Organization of an } \\
\text { Agricultural Market }\end{array}$ & $\begin{array}{l}\text { Long-term contracts, } \\
\text { fixed payment dates }\end{array}$ \\
\hline $\begin{array}{l}\text { Utilization of capacities, } \\
\text { distribution of source } \\
\text { materials }\end{array}$ & $\begin{array}{l}\text { Disorganization of the production } \\
\text { cycle, utilization is under } 50 \%\end{array}$ & $\begin{array}{l}\text { Transport problems, } \\
\text { kilometres between } \\
\text { slaughterhouses and } \\
\text { processors, upward price } \\
\text { adjustment }\end{array}$ & & Regional concentration \\
\hline Representative body & Several organizations & Disorganization & & $\begin{array}{l}\text { United representation, } \\
\text { centralization lead by one } \\
\text { organization }\end{array}$ \\
\hline
\end{tabular}

Source: author' own collection

companies can afford to slaughter only for loin in the summer grilling season just because there is demand for it. Markets for other regions of animals' bodies are to be searched for which is getting increasingly difficult with the media full of advertisements on healthy diet giving false information on pork and recommending only poultry meat (Juhász, 2008).

Hungarian consumer attitudes are easy to be influenced as a result of their price sensitivity. Retailers know it very well and take the opportunity. All this makes its effect felt on the suppliers' side, as meat prices are kept artificially low by these series of sales, causing increasing problems for both Hungarian processors and producers. Moreover, standards have been carefully stipulated thus creating considerable extra expenses, such as "shelf money", inclusion in sales etc. The situation is further aggravated by the lack of payment morals, i.e. in many cases liquidity for the actors of the product cycle is hampered by circumventing the deadline of payment laid down by regulations. This leads to constant goround debt, which hinders smooth production and the transport of goods; these are the deficiencies and problems why retailers prefer their own foreign suppliers, leaving scope for their own branded products which are often placed on the market under lower quality requirements and at cheaper prices than Hungarian products.

The analysis of the Hungarian meat industry indicated the concurrence of several factors, out of which only problems directly affecting processors will be highlighted. The most crucial of them is that capacity is under-utilized. It triggers high fixed costs in production and production costs are also high.

Bargaining positions in sales are weak as forces are not joined and there is no appropriate representative body on this level. Long-term contracts are not concluded by either producers or retailers, so their future is unpredictable and hazardous, giving an impetus for the boost of the black economy. Taken generally, it is impossible to follow up the product cycle.

The key problem in source material production is posed by the lack of own resources (Chikán, 2006). Producers do not possess their own lands, therefore they are unable to produce the necessary feedingstuff for their livestock and they are vulnerable to high cereal prices as fodder costs amount to the largest part of production costs.

They cannot afford to pay animal breeders and it is common practice that breeding animals are selected from their own fattening herds. Geneticists' efforts are in vain, as there is no solvent demand for their work on product cycle levels. If fattening farms worked with the appropriate genome, it would not lead to much more effective production due to the lack of good breeding technologies.

In terms of efficiency, the greatest problems are posed by low progeny number, slow weight gain and poor feed conversion, long fattening period, long sow rotation and high labour costs. Stables are out-of-date, they produce high 
Table 5: Competitive disadvantages on the level of source material production

\begin{tabular}{|c|c|c|c|c|}
\hline $\begin{array}{l}\text { Competitive disadvantages } \\
\text { es on the level source } \\
\text { material production }\end{array}$ & REASON & RESULT & Measures taken so far & $\begin{array}{l}\text { Suggestions for the } \\
\text { solution }\end{array}$ \\
\hline Lack of own resources & $\begin{array}{l}\text { Small farms, support has not } \\
\text { been successful }\end{array}$ & $\begin{array}{l}\text { Not credit-worthy, no } \\
\text { development, not competitive }\end{array}$ & & \\
\hline Slaughter-house & $\begin{array}{l}\text { Slaughter-cutting; further } \\
\text { processing }\end{array}$ & $\begin{array}{l}\text { Slaughter in itself is } \\
\text { unremunera-tive, there is no } \\
\text { specialization }\end{array}$ & & \\
\hline Breeding animal & $\begin{array}{l}\text { Breeding animal, privately } \\
\text { owned herd }\end{array}$ & $\begin{array}{l}\text { Farmers fail to use products } \\
\text { by Hungarian breeding } \\
\text { organizations, they use their } \\
\text { privately owned herds }\end{array}$ & & $\begin{array}{l}\text { Long-term contractual } \\
\text { relations between breeders } \\
\text { and producers }\end{array}$ \\
\hline Land & Pig breeders do not own lands & $\begin{array}{l}\text { There are no own resources } \\
\text { and fodder }\end{array}$ & $\begin{array}{l}\text { Act on Arable Land, merge } \\
\text { of micro and properties lands }\end{array}$ & Integration \\
\hline Weak efficiency indicators & $\begin{array}{l}\text { Progeny, death, feed conversion: } \\
\text { sow/piglet }\end{array}$ & $\begin{array}{l}\text { Non-competitive production, } \\
\text { perhaps only production } \\
\text { costs are covered on certain } \\
\text { farms }\end{array}$ & $\begin{array}{l}\text { Genetic experiments, } \\
\text { takeover of modern keeping } \\
\text { technologies }\end{array}$ & $\begin{array}{l}\text { Genetic experiments, } \\
\text { takeover of modern } \\
\text { keeping technologies }\end{array}$ \\
\hline
\end{tabular}

Source: author' own collection

running costs as a result of insufficient insulation, the removal and placement of manure is also problematic for lack of privately owned lands. Moreover, producers fail to join their forces, so they are unable to provide the continuous production of standard, quality source materials in bulk. As a result, their bargaining positions are weak and they cannot represent their own interests.

\section{Conclusion}

In contrast with developed Western-European countries, Hungarian farms are not specialized, although breeding animals and fattening pigs require diverse technologies. Our farm structure is both concentrated and disintegrated. The majority of pig breeders are vulnerable for lack of land as they are unable to produce the necessary amount of feedingstuffs and place manure safely.

The effective Act on Arable Land stipulates that selfsufficient animal farms shall not get access to land or shall no rent lands in the long run (up to 50 years) so property and land use are largely separated from livestock farming. In terms of efficiency, the greatest problems are posed by low progeny number, slow weight gain and poor feed conversion, long fattening period, long sow rotation and high labour costs. In the absence of modern farms high quality genome is not worth using. Solutions for the problem might be green or brown field investments, temporary disuse or disinfection of earlier fattening farms.

Due to geographical, economical-political and social reasons Hungarian meat producers cannot compete with developed pig producing countries. As a result of Hungary's location, the acquisition of protein sources and the export of pork to third countries are considerably more costly than for our competitors. Costs of heating and cooling are much higher than e.g. in Denmark, the Netherlands or Brazil, where temperature fluctuations are lower. Animal farms see the increasing number of crimes against property, so the establishment of safeguard services also increases production costs. Further problems are posed by the high interest rate of foreign capital (14-16\%), (MNB, 2008), the disorganization of the product cycle and the lack of technical advice.

In conclusion, the product cycles of the sector face a large number of problems on each level and solutions can only be provided by strategic decisions. It is not enough to improve certain levels of the product cycle, the sector needs to be analysed as a unit and problems are to be handled simultaneously.

\section{References}

AKI (2009): A versenyesélyek javitásának lehetőségei az élelmiszergazdaságban Agrárgazdasági Tanulmányok, 2009 Budapest: Agrárgazdasági Kutató Intézet.

Bartha A. (2008): 'Vész, fék - Megroggyant magyar versenyképesség', Heti világgazdaság, vol. 30, no. 41, pp. 99-103.

Chikán A. - Czakó E. - Kazainé Ónodi A. (2006): Gazdasági versenyképességünk vállalati nézópontból. Budapest: Corvinus Egyetem, Vállalatgazdaságtan Intézet, Versenyképességi Kutató Központ.

Juhász Á. (2008): 'Nemzetközi húsipari trendek', Mai Piac, vol. 17, no. 2, pp. 27-29.

KSH (2010): Mezőgazdaság, Gyorstájékoztató

MNB (2008): Elemzés a konvergencia-folyamatokról (2008 március). Budapest Magyar Nemzeti Bank.

Szakály Z. - Fülöp N. - Nábrádi A. (2008): 'Fogyasztói attitűdök elemzése a sertéshús és -húskészítmények piacán' in: A sertéságazat versenyképességének javitása. Debrecen.

Udovecz G. (szerk.) - Popp J. (szerk.) - Potori N. (szerk.) (2007): Alkalmazkodási kényszerben a magyar mezögazdaság - folytatódó lemaradás vagy felzárkózás? Agrárgazdasági Tanulmányok, 2007/7. szám. Budapest: Agrárgazdasági Kutató Intézet. 
